Remembrance of Pacific Pasts 



\section{Remembrance of Pacific Pasts}

\section{An Invitation to Remake History}

EDITED By Robert Borofsky

HAWAII PACIFIC UNIVERSITY

UNIVERSITY OF HAWAI'I PRESS, HONOLULU 


\section{Library of Congress Cataloging-in-Publication Data}

Remembrance of Pacific pasts : an invitation to remake history / edited by Robert Borofsky. p. cm.

Includes bibliographical references and index.

ISBN 0-8248-2189-0 (cloth : alk. paper) -

ISBN 0-08248-2301-X (paper : alk. paper)

Identifiers: LCCN 2018037380 | ISBN 9780824875268 (cloth ; alk. paper)

1. Pacific Area-Civilization. 2. Public opinion-Pacific Area. 3. Pacific Area-Foreign public opinion. I. Borofsky, Robert, 1944

DU28.3.R45 2000

909'.09823- dc21

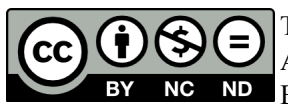

The open-access version of this book is licensed under Creative Commons Attribution-NonCommercial-NoDerivatives 4.0 International (CC and shared for non-commercial purposes, provided credit is given to the author. Derivative works and commercial uses require permission from the publisher. For details, see https://creativecommons.org/licenses/by-nc-nd/4.0/.

The open-access edition of this title was made possible with the generous support of the editor. The ISBNs for the open-access editions are 9780824888015 (PDF) and 9780824888022 (EPUB). 
$\tau_{0}$

Lynette Cruz, Greg Dening,

Epeli Hau'ofa, Marshall Sahlins, and Albert Wendt, whose writings and words inspired this volume 
Follow one word, back

"Mai" Come.

from Hawai'i

Back across the wide green water

all the way to Indonesia ... "Mai"

Means, "Come" in Bahasa Bali, the old tongue

Think of them leaving

Men and women on boats laid low with pigs,

Coconut, yams, tapioca, taro root, a pregnant dog.

That last real Indonesian on the way to becoming

The first Hawaiian

By what river of current crossing?

Stopping along the way to become Maori, Samoan, Fijian,

Tahitian...

Who chartered them with bamboo maps to Easter Island?

They took Gods, Goddesses, seeds and pottery which breaks,

Like clay postcards.

This baby has no English yet.

"Mai" he sings, sweeping a fat hand toward his heart.

"Come, come to me."

Follow one word forward,

Follow one forward from each new child who speaks.

"Mai" by Robin Lim, reprinted from bamboo ridge: A Hawai'i’s Writers Journal 73, Spring 1998 (Honolulu: Bamboo Ridge Press): 225. 